\title{
Penerapan Metode Fuzzy Tsukamoto Dalam Penentuan Harga Laptop Bekas
}

\author{
July Yanti Marpaung, Guidio Leonarde Ginting ", Natalia Silalahi \\ Program Studi Teknik Informatika, Universitas Budi Darma, Medan, Indonesia \\ Email: 1julyanti@gmail.com,,"*guidio.leonarde@stmik-budidarma.ac.id
}

\begin{abstract}
Abstrak
Kebijaksanaan dalam mengambil sebuah keputusan pada permasalahan tertentu bukan lah hal yang mudah, karena terlalu dilakukan pertimbangan yang diharapkan dapat membantu memberikan alasan keputusan tertentu harus diambil. Begitu juga penanganan masalah menentukan harga satuan unit laptop yang bekas pada CV. Sumber Jaya Computer Medan.Jenis Laptop bekas yang ditentukan harganya akan lebih mudah jika dulakukan dengan suatu aplikasi, karena sudah melakukan penilaian, maka hal yang diperlukan adalah seperti kuwalitas suatu laptop bekas sesuai dengan harganya, processor, harddisk, memory, VGA, Lama Pemakaian. Sistem pendukung keputusan penentuan suatu harga leptop sangat tepat diterapkan untuk penanganan masalah yang membutuhkan penyelesaian mandiri dari komputer untuk pemrosesan data spesifikasi yang mengikuti seleksi dengan perhitungan efisien dan akurat. Dengan menggunakan penalaran Logika Fuzzy Tsukamoto dalam pemrosesan data input dan output, serta informasi pendukung berapa ranking sangat mendukung dalam pengambilan keputusan untuk menentukan suatu harga laptop bekas.
\end{abstract}

Kata Kunci: SPK; Fuzzy Tsukamoto; Laptop Bekas

\begin{abstract}
The wisdom in taking a decision on a particular problem is not an easy thing, because too much consideration is taken which is expected to help give a reason certain decisions must be taken. Likewise, the handling of the problem determines the price of used laptop units on the CV. Sumber Jaya Computer Medan. The type of used laptop that is determined by the price will be easier if it is done with an application, because it has done an assessment, then the things needed are like the quality of a used laptop according to the price, processor, hard disk, memory, VGA, Old Usage. Decision support system for determining a leptop price is very appropriate to be applied for handling problems that require self-resolution of computers for processing data specifications that follow selection with efficient and accurate calculations. By using Tsukamoto Fuzzy Logic reasoning in the processing of input and output data, as well as supporting information how much ranking is very supportive in making decisions to determine the price of a used laptop.
\end{abstract}

Keywords: DSS; Fuzzy Tsukamoto; Used Laptops

\section{PENDAHULUAN}

Laptop merupakan kebutuhan dasar bagi masyarakat baik untuk segi pendidikan maupun aktifitas bisnis maupun keguaan lainnya. Era serba teknologi zaman sekarang laptop bikan lagi menjadi kebutuhan yang khusus untuk kalangan menegah keatas, dikarenakan laptop saat ini bukan lagi alat elektronik yang dikategorikan mahal, disamping ringan dibawa keman saja laptop juga bias digunakan kapan saja, namun jika dikaji lebih dalam, laptop (notebook) dapata dikategorikan dua jenis yaitu baru dan bekas.

Laptop dipasaran saat ini semmakin banyak mulai dari toko elektronik, toko laptop, service laptop, dan banyak lagi dipasaran termasuk di kalangan jual-beli online, dalam penjualan online juga tidak hanya menjual laptop yang baru melainkan ada juga yang kekas, yang baru sudah pasti menggunakan sparepart yang baru, dalam hal yang bekas banyak yang sering keliru, baik dalam melihat kondisi kualitas dari luar maupun kondisi sparepart yang didalam, sparepart maupun hardware yang didalam sering terjadi kesalahan atau tidak sesuai dengan tulisan spesifikasi yang ditulis di laptop, disamping banyaknya pilihan tersedia di pasaran bisa membuat tambah bingung untuk memilihnya, dalam hal ini membahas laptop yang bekas (second).

Dalam hal menentukan nilai jual laptop yang baru tidak sama dengan menentukan nilai jual laptop yang bekas, untuk menentukan harga laptop yang bekas tidaklah mudah, melainkan harus di lihat terlebih dahulu kondisi-kondisi hardware. Dari segi hardware juga tidak semua wujudnya kelihatan, melainkan harus dibongkar terlebih dahulu untuk melihat kondisi bagian dalam, ditambah lagi untuk menentukan spesifikasi laptop supaya harga bandrolnya bisa ditentukan untuk dipasarkan harus juga melihat harga pasaran.

Tsukamoto merupakan salah satu bentuk metode penilaian kinerja dengan melakukan pendekatan kepada pihak yang melakukan penilaian. Penilaian tidak hanya dilakukan oleh satu pihak saja atau, tetapi juga dilakukan oleh orang yang ahli dan memiliki kemampuan dalam memahami tentang perangkat keras dan perangkat lunak tentang laptop. Apabila telah dilakukan penilaian dalam beberapa ahli, maka diperlukan proses pemantauan dan evaluasi yang dilakukan oleh pihak penentu yang ahli dalam bidang tersebut. Pada dasarnya, metode tsukamoto mengaplikasikan penalaran monoton pada setiap aturannya. Karena menggunakan konsep dasar penalaran monoton, pada metode tsukamoto, setiap konsekuen pada aturan yang berbentuk IF-THEN harus direpresentasikan dengan suatu himpunan fuzzy dengan fungsi keanggotaan yang monoton.

Berdasarkan penelitian terdahulu oleh [1] N.Novita,"Metode Fuzzy Tsukamoto Untuk Menentukan Beasiswa”, Jurnal \& Penelitian Teknik Informatika, Vol.1. 2016. Menyimpulkan bahwa metode fuzzy tsukamoto dapat menentukan banyaknya nilai uang beasiswa kepada si penerima basiswa, dengan nilai nilai IP (Indeks 
Prestasi) dari masing masing mahasiswa yang sudah di tentukan berdasarkan kriteria-kriteria yang sudah diterapkan. Juga dengan penelitian oleh [2] Mulyan Ali," Penerapan Metode Fuzzy Tsukamoto Untuk Menentukan Jumlah Jam Overtime Pada Produksi Barang di PTAsahi Best Base Indonesia (ABBI) Bekasi”, Jurnal Informatika SIMANTIK, Vol.1. 2016. Juga menyimpulkan bahwa penentuan jumlah overtime dengan menggunakan metode fuzzy Tsukamoto menggunakan tiga variable sebagai input datanya, persediaan barang, permintaan dan output barang ternyata lebih efektif dibanding perhitingan secara manual karena pada metode tsukamoto ini untuk menentukan hasil diperlukan tahapan-tahapan yang spesifik seperti fuzzyfikasi, rule, implikasi serta defuzzyfikasi.

Dari beberapa penelitian terdahulu yang menggunakan metode fuzzy tsukamoto yang juga dipergunakan sebagai metode dalam mengambil keputusan, dari beberapa jurnal, maka dengan ini penulis membuat kesimpulan bahwa metode dalam penelitian ini menggunakan metode fuzzy tsukamoto dalam penentuan harga laptop bekas.

\section{METODE PENELITIAN}

\subsection{Sistem Pendukung Keputusan}

Sistem Pendukung Keputusan (SPK) merupakan sistem informasi intreaktif yang menyediakan informnasi, pemodelan dan pemanipulasian data. Sistem itu digunakan untuk membantu pengambilan keputusan dalam situasi yang semiterstruktur dan situasi yang tidar terstruktur, di mana tak seorang pun tahu secara pasti bagaimana keputusan harusnya di buat [4]

Sistem pendukung keputusan biasanya dibangun untuk mendukung solusi atas suatu masalah atau mengevaluasi suatu peluang. Aplikasi DSS digunakan dalam pengambilan keputusan.Menurut Tata Sutabri Dalam managemen, pengambilan keputusan (decision making) memegang peranan tang sangat penting karena keputusan yang di ambil oleh manager merupakan hasil pemikiran akhir yang harus dilaksanakan oleh bawahannya atau mereka yang bersangkuta dengan organisasi yang di pimpin [5].

\subsection{Metode Tsukamoto}

Dalam membangun sebuah sistem fuzzy dikenal beberapa metode penalaran, antara lain : metode Tsukamoto, metode Mamdani dan metode Sugeno.

Pada metode Tsukamoto, setiap konsekuen pada aturan yang berbentuk IF-THEN harus direpresentasikan dengan suatu himpunan fuzzy dengan fungsi keanggotaan yang monoton. Sebagai hasilnya, output hasil inferensi dari tiap-tiap aturan diberikan dengan tegas (crisp) berdasarkan $\alpha$-predikat (fire strength). Hasil akhirnya diperoleh dengan menggunakan rata-rata terbobot.

Misal ada 2 variabel input, var-1(x) dan var-2(y) serta 1 variabel output var-3(z), dimana var-1 terbagi atas 2 himpunan yaitu A1 dan A2 dan var-2 terbagi atas himpunan B1 dan B2. Sedangkan var-3 juga terbagi atas 2 himpunan yaitu C1 dan C2. (Kusumadewi, 2003).

Ada dua aturan yang digunakan yaitu:

[R1] IF ( $x$ is Al) and ( $y$ is B2) THEN ( $z$ is $C 1$ )

[R2] IF ( $x$ is A2) and (y is B1) THEN ( $z$ is $C 2$ )

\subsection{Laptop}

Kata Laptop sendiri berasal dari kata "Lap" dalam bahasa inggris yakni pangkuan. Yang dimaksud pangkuan disini adalah laptop bisa dipakai di pangkuan sekitar paha saat sedang duduk dan top yang berarti menandakan posisi laptop ini berada di pangkuan dan menghadap ke atas maksudnya ke pengguna. Laptop atau komputer jinjing adalah komputer bergerak yang berukuran relatif kecil dan ringan, beratnya berkisar dari 1-6 kg, tergantung pada ukuran, bahan, dan spesifikasi laptop tersebut. Sumber daya laptop berasal dari baterai atau adaptor A/C yang dapat digunakan untuk mengisi ulang baterai dan menyalakan laptop itu sendiri. Baterai laptop pada umumnya dapat bertahan sekitar 1 hingga 6 jam sebelum akhirnya habis, tergantung dari cara pemakaian, spesifikasi, dan ukuran baterai. Laptop terkadang disebut juga dengan komputer notebook atau notebook saja.

\section{ANALISA DAN PEMBAHASAN}

Analisis merupakan penguraian dari suatu sistem yang utuh kedalam bagian-bagian komponennya dengan maksud untuk mengidentifikasikan dan mengevaluasi permasalahan-permasalahan, kesempatan-kesempatan hambatanhambatan yang terjadi dan kebutuhan-kebutuhan yang diharapkan sehinnga dapat diusulkan perbaikan perbaikannya. Hal-hal yang dianalisis pada tahap analisis ini adalah analisis masalah, analisis fungsional, analisis prosedur sistem yang sedang berjalan, analisis aliran informasi, analisis pengkodean, analisis basis data, dan analisis kebutuhan non-fungsional pada penentuan harga laptop bekas.

Dari tahap analisis dapat diketahui dengan jelas masalah-masalah apa saja yang sering muncul, bagaimana user menggunakan sistem yang berjalan sampai solusi yang dapat diajukan untuk memecahkan masalah tersebut. Berdasarkan hasil penelitian yang dilakukan, didapatkan bahwa : 
1. Proses pengecekan jenis-jenis untuk pemilihan laptop bekas belum secara otomatis mengambil keputusan sendiri mana saja laptop yang memenuhi syarat untuk keperluan sehingga mengakibatkan salah memilih jenis laptop sehingga menimbulkan kerugian pada konsumen.

2. Proses menganalisis beberapa karyawan CV.Sumber Jaya Computer yang menjual laptop tidak sesuai dengan bobot untuk dijual sesuai dengan harga.

3. Tidak adanya kepastian dalam bentuk pendukung keputusan untuk menentukan harga suatu laptop sehingga dalam memberikan suatu harga laptop bekas harus diperiksa manual sehingga penentuan suatu harga laptop bekas memakan waktu, hal ini menyebabkan CV. Sumber Jaya Computer sulit melayani pembeli.

Metode Tsukamoto merupakan proses membandingkan antara kompetensi individu sehingga dapat diketahui perbedaan kompetensinya. Variabel-variabel yang dipelukan dalam pembuatan sistem penunjang keputusan untuk penentuan harga laptop bekas dengan logika fuzzy tsukamoto pada CV. Sumber Jaya Computer antara lain :

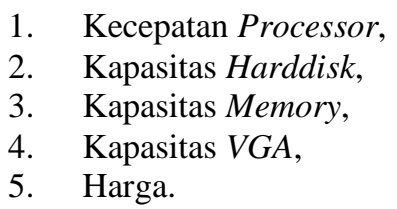

\subsection{Penerapan Metode Tsukamoto}

Pada metode Tsukamoto, setiap konsekuen pada aturan yang berbentuk IF-THEN harus direpresentasikan dengan suatu himpunan fuzzy dengan fungsi keanggotaan yang monoton. Sebagai hasilnya, output hasil inferensi dari tiap-tiap aturan diberikan dengan tegas (crisp) berdasarkan $\alpha$-predikat (fire strength). Hasil akhirnya diperoleh dengan menggunakan rata-rata terbobot. Tahapan dalam perancangan sistem fuzzy ialah sebagai berikut :

1. Mendefinisikan model masukan dan keluaran sistem, dalam kasus ini terdapat 5 model masukan/variabel input yang terdiri dari: processor, Harddisk, Memory, VGA, Harga. Dan 1 model keluaran/variabel output yang berupa hasil.

2. Dekomposisi variabel model menjadi himpunan fuzzy, yaitu:

Dari variabel-variabel input dibentuk himpunan-himpunan fuzzy antara lain:

a. Processos yang terdiri dari 3 himpunan fuzzy, yaitu: rendah, cukup, tinggi.

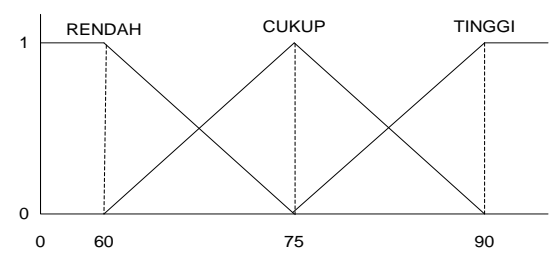

Gambar 1. Variabel Processor

Fungsi keanggotaan :

$$
\begin{aligned}
& \mu \text { Processor Rendah }\left\{\begin{array}{lc}
1 ; & 0 \leq x \leq 60 \\
\frac{75-x}{75-60} ; & 60 \leq x \leq 75 \\
0 ; & x \geq 75
\end{array}\right. \\
& \mu \text { Processor Sedang } \begin{cases}0 ; & 90 \leq x \leq 60 \\
\frac{x-60}{75-60} ; & 75 \leq x \leq 75 \\
\frac{90-\mathrm{x}}{90-75} ; & x \leq 75\end{cases} \\
& \mu \text { Processor Tinggi } \begin{cases}0 ; & 75 \leq x \leq 90 \\
\frac{x-75}{90-75} ; & x \geq 90 \\
1 ; & \end{cases}
\end{aligned}
$$

b. Variabel Harddisk yang terdiri dari 3 himpunan fuzzy, yaitu : rendah, cukup, tinggi.

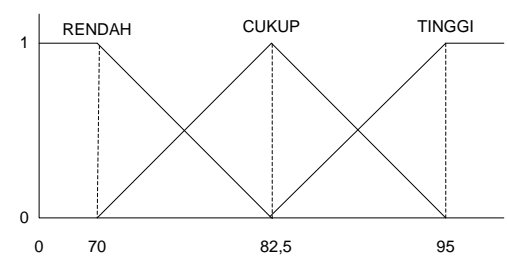

Gambar 2. Variabel Harddisk 
Fungsi keanggotaan :

$$
\begin{aligned}
& \mu \text { Harddisk Rendah }\left\{\begin{array}{lc}
\frac{1 ;}{82,5-x} 82,5-70 & 0 \leq x \leq 70 \\
0 ; & x \geq 82,5
\end{array}\right. \\
& \mu \text { Harddisk Sedang }\left\{\begin{array}{lc}
0 ; & 95 \leq x \leq 70 \\
\frac{x-70}{82,5-70} ; & 70 \leq x \leq 82,5 \\
\frac{95-x}{95-82,5} ; & 82,5 \leq w \leq 95
\end{array}\right. \\
& \mu \text { Harddisk Tinggi }\left\{\begin{array}{lc}
0 ; & x \leq 82,5 \\
\frac{x-82,5}{95-82,5} ; & 82,5 \leq x \leq 95 \\
1 ; & x \geq 95
\end{array}\right.
\end{aligned}
$$

c. Variabel Memory yang terdiri dari 3 himpunan fuzzy, yaitu : rendah, cukup, tinggi.

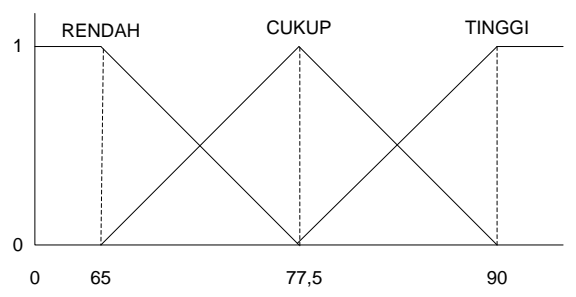

Gambar 3. Variabel Memory

Fungsi keanggotaan ;

$$
\begin{aligned}
& \mu \text { Memory Rendah }\left\{\begin{array}{lc}
1 ; & x \leq 65 \\
\frac{77,5-x}{77,5-65} ; & 65 \leq x \leq 77,5 \\
0 ; & x \geq 77,5
\end{array}\right. \\
& \mu \text { Memory Sedang }\left\{\begin{array}{lc}
0 ; & 90 \leq x \leq 65 \\
\frac{x-65}{77,5-65} ; & 65 \leq x \leq 77,5 \\
\frac{90-\mathrm{x}}{90-77,5} ; & 77,5 \leq x \leq 90 \mathrm{x}=77,5
\end{array}\right. \\
& \mu \text { Memory Tinggi } \begin{cases}0 ; & x \leq 77,5 \\
\frac{x-77,5}{90-77,5} ; & 77,5 \leq x \leq 90 \\
1 ; & x \geq 90\end{cases}
\end{aligned}
$$

d. Variabel Monitor (LCD) yang terdiri dari 3 himpunan fuzzy, yaitu : rendah, cukup, tinggi.

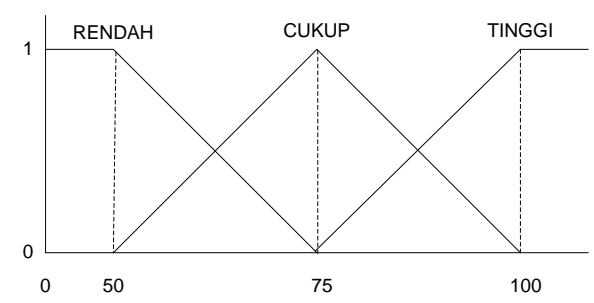

Gambar 4. Variabel Monitor (LCD)

Fungsi keanggotaan :

$$
\begin{gathered}
\mu \text { Monitor Rendah }\left\{\begin{array}{lc}
1 ; & x \leq 50 \\
\frac{75-x}{75-50} ; & 50 \leq x \leq 75 \\
0 ; & x \geq 75
\end{array}\right. \\
\mu \text { Monitor Sedang }\left\{\begin{array}{lc}
0 ; & x \leq 50 \\
\frac{x-50}{75-50} ; & 50 \leq x \leq 75 \\
\frac{100-\mathrm{x}}{100-75} ; & 75 \leq x \leq 100 \quad \mathrm{x}=75
\end{array}\right.
\end{gathered}
$$




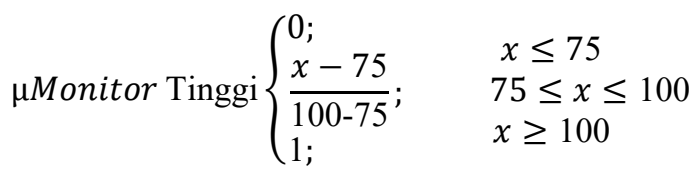

e. Variabel Lama Pakai yang terdiri dari 3 himpunan fuzzy, yaitu : rendah, cukup, tinggi.

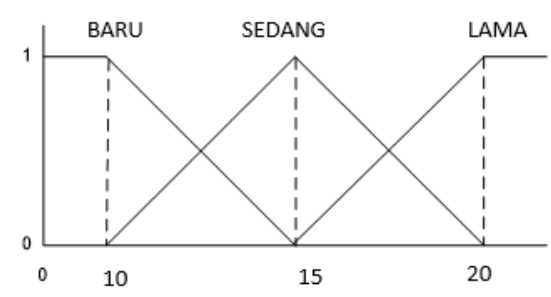

Gambar 5. Variabel Lama Pakai

Fungsi keanggotaan :

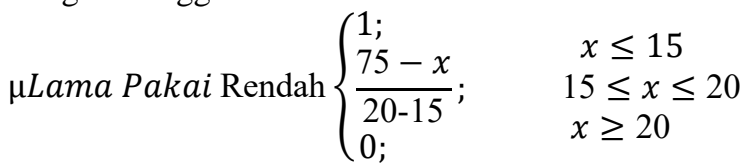

$\mu$ Lama Pakai Sedang $\left\{\begin{array}{lc}0 ; & x \leq 15 \\ \frac{x-15}{20-15} ; & 15 \leq x \leq 20 \\ \frac{25-\mathrm{x}}{25-20} ; & 20 \leq x \leq 25 \quad \mathrm{x}=20\end{array}\right.$

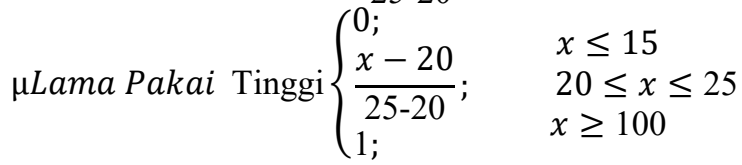

f. Variabel Harga yang terdiri dari 3 himpunan fuzzy, yaitu : rendah, cukup, tinggi.

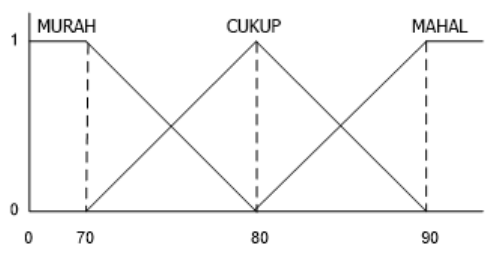

Gambar 6. Variabel Harga

Fungsi keanggotaan ;

$\mu$ Harga Rendah $\left\{\begin{array}{lc}1 ; & x \leq 70 \\ \frac{80-x}{80-70} ; & 70 \leq x \leq 80 \\ 0 ; & x \geq 80\end{array}\right.$

$\mu$ Harga Sedang $\left\{\begin{array}{cc}0 ; & x \leq 70 \\ \frac{x-70}{80-70} ; & 70 \leq x \leq 80 \\ \frac{70-\mathrm{x}}{90-80} ; & 80 \leq x \leq 90 \quad \mathrm{x}=80\end{array}\right.$

$\mu$ Harga Tinggi $\begin{cases}0 ; & x \leq 80 \\ \frac{x-80}{90-80} ; & 80 \leq x \leq 90 \\ 1 ; & x \geq 90\end{cases}$

3. Pembuatan Aturan Fuzzy

Dari ke lima variabel input dan sebuah variabel output yang telah didefinisikan, dengan melakukan analisa data terhadap batas tiap-tiap himpunan fuzzy pada tiap- tiap variabelnya.

4. Proses Logika Fuzzy:

a. Fuzzifikasi, merupakan proses untuk mendapatkan derajat keanggotaan dari sebuah nilai numerik masukan (crisp).

Representasi yang digunakan pada kasus ini untuk mendapatkan derajat keanggotaan untuk himpunan baik, 
cukup, dan kurang pada variabel Processor adalah dengan menggunakan representasi kurva bentuk bahu. Misal diambil salah satu Laptop dengan nilai untuk masing-masing variabel berturut-turut sebagai berikut : 75, 82,55, 77, 20, 80.

Fuzzifikasi variabel Processor dengan nilai Processor 75.

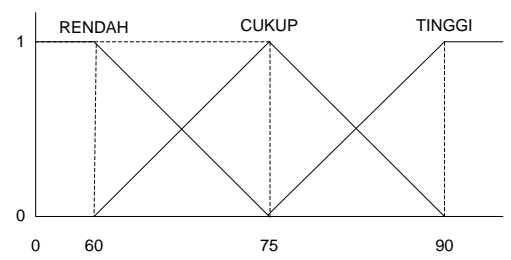

Gambar 7. Variabel Processor (75)

Untuk mencari nilai derajat keanggotaan dari nilai 75 digunakan persamaan $\mu$ ProcessorCUKUP(75) $=1$

Fuzzifikasi variabel Harddisk dengan nilai Harddisk 77,5.

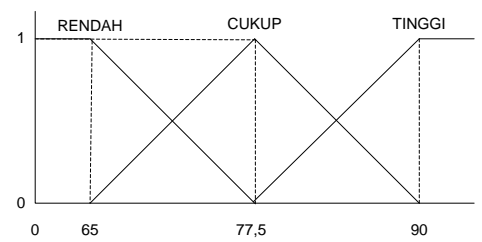

Gambar 8. Variabel Harddisk $(77,5)$

Untuk mencari nilai derajat keanggotaan dari nilai 77,5 dengan persamaan $\mu$ Harddsik CUKUP(75) $\quad=1$

Fuzzifikasi variabel Memory dengan nilai Memory 75

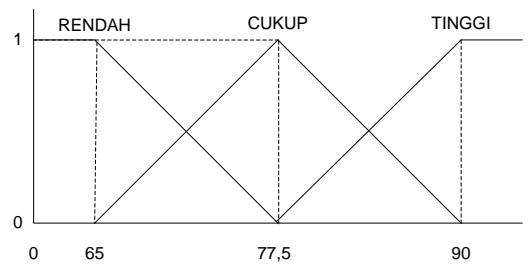

Gambar 9. Variabel Memory (75)

Untuk mencari nilai derajat keanggotaan dari nilai 75 digunakan persamaan $\mu$ MemoryCUKUP(75) $=1$

Fuzzifikasi variabel Monitor dengan nilai Monitor 75

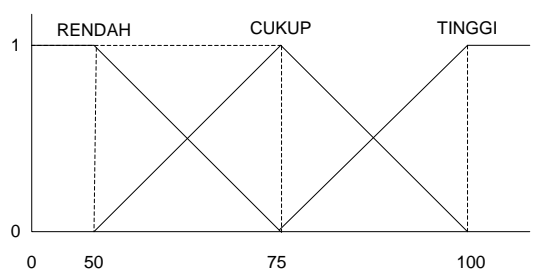

Gambar 10. Variabel Monitor (75)

Untuk mencari nilai derajat keanggotaan dari nilai 75 digunakan persamaan. $\mu$ Monitor CUKUP $(77)=1$ Fuzzifikasi variabel Lama Pakai dengan nilai Monitor 75

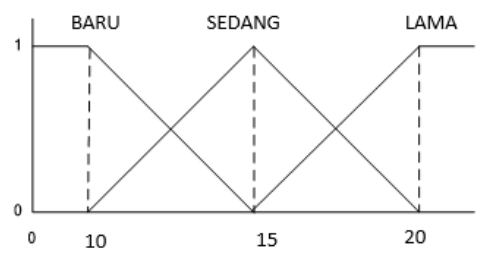

Gambar 11. Variabel Monitor(75) 
Untuk mencari nilai derajat keanggotaan dari nilai 75 digunakan persamaan (4.11). $\mu$ Monitor CUKUP (77) $=1$ Fuzzifikasi variabel Harga dengan nilai Lama Pakai 80

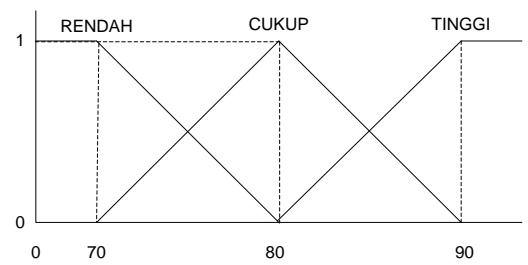

Gambar 12. Lama Pakai (80)

Untuk mencari nilai derajat keanggotaan dari nilai 80 digunakan persamaan. $\mu$ Lama Pakai CUKUP $(80)=1$

Selanjutnya nilai derajat keanggotaan tersebut diimplementasikan kedalam aturan fuzzy.

b. Aplikasi fungsi implikasi, dimana penggunaan Fungsi MIN sebagai Metode Implikasinya dalam menentukan $\alpha$-predikat minimum dari tiap-tiap aturan yang ditetapkan, maksudnya dari beberapa pernyataan IF tersebut diambil $\alpha$-predikat atau nilaiderajat keanggotaan terkecil. Berikut hasil implikasi (hasil implikasi yang bernilai 0 diabaikan)

-IF Processor cukup AND Harddisk cukup AND Memory cukup AND VGA cukup AND Harga cukup THEN hasil memuaskan

$\alpha$-predikat (derajat keanggotaan terkecil/minimum):

$=\mu$ Processor CUKUP $\mu$ HarddiskCUKUP $; \mu$ MemoryCUKUP $\mu$ VGA CUKUP; $\mu$ HargaCUKUP

$=$ MIN $(\mu$ ProcessorCUKUP[75], $\mu$ HarddiskCUKUP[82,5], $\mu$ MemoryCUKUP [77,5], $\mu$ VGA CUKUP [75], $\mu$ HargaCUKUP[80])

$=\operatorname{MIN}(1 ; 1 ; 1 ; 1 ; 1)$

$=1$

-IF processor cukup AND harddissk cukup AND memory cukup AND VGA cukup AND harga cukup THEN hasil cukup $\alpha$-predikat (derajat keanggotaan terkecil/minimum):

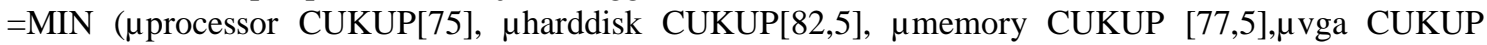
[75], $\mu$ harga CUKUP[80])

$=$ MIN $(1 ; 1 ; 1 ; 1 ; 1)$

$=1$

c. Defuzzifikasi, proses untuk merubah hasil penalaran yang berupa derajat keanggotaan keluaran $(\alpha-$ predikat) menjadi variabel numerik kembali (crisp). Berikut hasil defuzzifikasi (Nilai defuzzy 0 diabaikan karena tidak berpengaruh terhadap sistem)

$$
\begin{array}{rrl}
\text { [R122] } & (z-50) /(95-50) & =1 \\
z=95 & \\
{[R 244]} & (95-z) /(95-50) & =1 \\
z & =50
\end{array}
$$

Defuzzifikasi itu sendiri merupakan suatu proses untuk merubah hasil penalaran yang berupa derajat keanggotaan keluaran ( $\alpha$-predikat) menjadi variabel numerik kembali (crisp). Sistem akhir Penentuan Harga Laptop Bekas teladan ini menggunakan rata-rata terbobot (weight average) sebagai metode Defuzzifikasi untuk mendapatkan hasil akhir penentuan harga laptop. Adapun rumus rata-rata terbobot tersebut adalah sebagai berikut: $z=\frac{\alpha_{1} z_{1}+\alpha_{2} z_{2}+\ldots+\alpha_{n} z_{n}}{\alpha_{1}+\alpha_{2}+\cdots+\alpha_{n}}$

Keterangan :

$\mathrm{z} \quad=$ Hasil penilaian harga laptop

$\alpha_{n} \quad=$ Derajat Keanggotaan dari Aturan ke- $\mathrm{n}$

$\mathrm{Z}_{\mathrm{n}} \quad=$ nilai dari Aturan ke- $\mathrm{n}$

Semua nilai selain angka 0 (nol) pada perhitungan defuzzifikasi dimasukkan kedalam rumus menghasilkan:

$z=\frac{1 * 95+1 * 50}{1+1}$

$\mathrm{z}=72,5$

Berdasarkan pada tahapan algoritma fuzzy tsukamoto, karena sudah dilakukan pendefinisian variabel input dan output, serta dekomposisi himpunan setiap variabel, maka tahapan selanjutnya ialah fuzzifikasi.

Fuzzifikasi variabel processor dengan nilai processor laptop 75. 


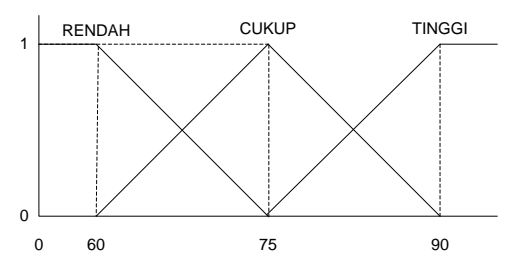

Gambar 13. Fuzzyfikasi variabel prosesor

Untuk mencari nilai derajat keanggotaan dari nilai 75 digunakan persamaan $\mu$ processor CUKUP(75) $=1$

Fuzzifikasi variabel harddisk dengan nilai harddsisk laptop bekas 70 .

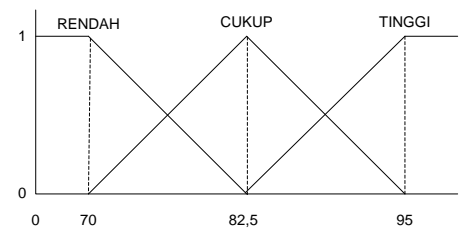

Gambar 14. Fuzzyfikasi variabel harddisk

Untuk mencari nilai derajat keanggotaan dari nilai 70 dengan persamaan $\mu$ harddisk RENDAH(70) $=1$

Fuzzifikasi variabel memory dengan nilai memory laptop bekas 85

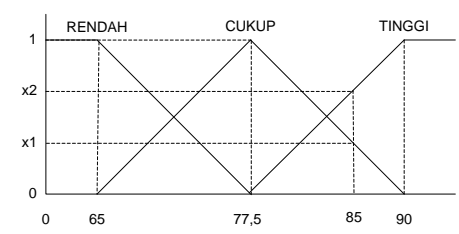

Gambar 15. Fuzzyfikasi variabel memory

Untuk mencari nilai derajat keanggotaan dari nilai 85 digunakan persamaan $\mu$ Harddisk CUKUP $(85) \quad=(90-85) /(90-77,5)$

$\mu$ Harddisk TINGGI $(85) \quad=(85-77,5) /(90-77,5)$

$$
=0,6
$$

Fuzzifikasi variabel vga dengan nilai vga Laptop Bekas 85

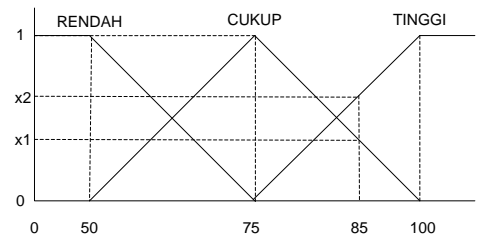

Gambar 16. Fuzzyfikasi variabel vga

Untuk mencari nilai derajat keanggotaan dari nilai 75 digunakan persamaan $\mu$ vga CUKUP $(75) \quad=(100-85) /(100-75)$

$\mu$ vga TINGGI $(75) \quad=(85-75) /(100-75)$

$$
=0,4
$$

Fuzzifikasi variabel harga dengan nilai harga laptop bekas 75

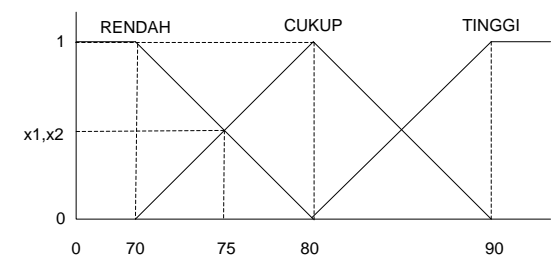

Gambar 17. Fuzzyfikasi variabel harga 
Building of Informatics, Technology and Science (BITS)

Volume 2, No 2, December 2020 Page 115-126

ISSN 2684-8910 (media cetak)

ISSN 2685-3310 (media online)

Untuk mencari nilai derajat keanggotaan dari nilai 75 digunakan persamaan

$\mu$ harga RENDAH(75) $\quad=(75-70) /(80-70)$

$$
=0,5
$$

$\mu$ harga CUKUP $(75) \quad=(80-75) /(80-70)$

$$
=0,5
$$

Selanjutnya nilai derajat keanggotaan tersebut diimplementasikan kedalam aturan fuzzy.

-IF processor cukup AND harddisk rendah AND memory tinggi AND vga tinggi AND harga cukup THEN hasil memuaskan

$\alpha$-predikat (derajat keanggotaan terkecil/minimum):

$=\mu$ processor CUKUP; $\mu$ harddisk RENDAH; $\mu$ memory TINGGI^ $\mu$ vga TINGGI; $\mu$ harga CUKUP

$=$ MIN ( $\mu$ processor CUKUP[75], $\mu$ harddisk RENDAH[70], $\mu$ memory TINGGI [85], $\mu$ vga TINGGI [85], $\mu$ harga

CUKUP[75])

$=$ MIN $(1 ; 1 ; 0,6 ; 0,4 ; 0,5)$

$=0,4$

Defuzzifikasi : (z-50)/(95-50) $\quad \begin{aligned} & =0,4 \\ \mathrm{z} & =68\end{aligned}$

- IF processor cukup AND harddisk rendah AND memory tinggi AND vga tinggi AND harga rendah THEN hasil memuaskan

$\alpha$-predikat (derajat keanggotaan terkecil/minimum):

$=\mu$ procrssor CUKUP; $\mu$ harddisk RENDAH; $\mu$ memory TINGGI $\sim \mu$ vga TINGGI; $\mu$ harga RENDAH

$=$ MIN ( $\mu$ processor CUKUP[75], $\mu$ harddisk RENDAH[70], $\mu$ memory TINGGI [85], $\mu$ vga TINGGI [85], $\mu$ harga RENDAH[75])

$=\operatorname{MIN}(1 ; 1 ; 0,6 ; 0,4 ; 0,5)$

$=0,4$

Defuzzifikasi : (z-50)/(95-50)

$$
\begin{aligned}
& =0,4 \\
& =68
\end{aligned}
$$

-IF processor cukup AND harddisk rendah AND memory tinggi AND vga cukup AND harga cukup THEN hasil memuaskan

$\alpha$-predikat (derajat keanggotaan terkecil/minimum):

$=\mu$ processor CUKUP $; \mu$ harddisk RENDAH $; \mu$ memory TINGGI $\sim \mu$ vga CUKUP $; \mu$ harga CUKUP

$=$ MIN ( $\mu$ processor CUKUP[75], $\mu$ harddisk RENDAH[70], $\mu$ memory TINGGI [85], $\mu$ vga CUKUP [85], $\mu$ harga

CUKUP[75])

$=\operatorname{MIN}(1 ; 1 ; 0,6 ; 0,6 ; 0,5)$

$=0,5$

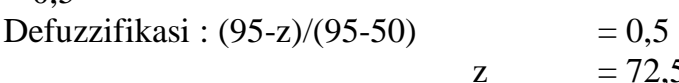

-IF processor cukup AND harddisk rendah AND memory tinggi AND vga cukup AND harga rendah THEN hasil memuaskan

$\alpha$-predikat (derajat keanggotaan terkecil/minimum):

$=\mu$ processor CUKUP; $\mu$ harddisk RENDAH; $\mu$ memory TINGGIn $\mu$ vga CUKUP; $\mu$ harga RENDAH

$=$ MIN ( $\mu$ processor CUKUP[75], $\mu$ harddisk RENDAH[70], $\mu$ memory TINGGI [85], $\mu$ vga CUKUP [85], $\mu$ harga RENDAH[75])

$=\operatorname{MIN}(1 ; 1 ; 0,6 ; 0,6 ; 0,5)$

$=0,5$

Defuzzifikasi : $(95-z) /(95-50)$

$$
=0,5
$$$$
=72,5
$$

-IF processor cukup AND harddisk rendah AND memory cukup AND vga tinggi AND harga cukup THEN hasil cukup

$\alpha$-predikat (derajat keanggotaan terkecil/minimum):

$=\mu$ processor CUKUP $; \mu$ haeddisk RENDAH $; \mu$ memory CUKUP $; \mu$ vga TINGGI; $\mu$ harga CUKUP

$=$ MIN ( $\mu$ processor CUKUP[75], $\mu$ harddisk RENDAH[70], $\mu$ memory TINGGI [85], $\mu$ vga CUKUP [85], $\mu$ harga

CUKUP[75])

$=\operatorname{MIN}(1 ; 1 ; 0,4 ; 0,4 ; 0,5)$

$=0,4$

$$
\begin{array}{rll}
\text { Defuzzifikasi : }(95-\mathrm{z}) /(95-50) & & =0,4 \\
\mathrm{z} & =77
\end{array}
$$

- IF processor cukup AND harddisk rendah AND memory cukup AND vga tinggi AND harga rendah THEN hasil cukup $\alpha$-predikat (derajat keanggotaan terkecil/minimum):

$=\mu$ processor CUKUP $; \mu$ harddisk RENDAH ; $\mu$ memory CUKUP $\sim \mu$ vga TINGGI; $\mu$ harga RENDAH

$=\mathrm{MIN}$ ( $\mu$ processor CUKUP[75], $\mu$ harddisk RENDAH[70], $\mu$ memory TINGGI [85], $\mu$ vga CUKUP [85], $\mu$ harga

RENDAH[75]) 
Building of Informatics, Technology and Science (BITS)

Volume 2, No 2, December 2020 Page 115-126

ISSN 2684-8910 (media cetak)

ISSN 2685-3310 (media online)

$=\operatorname{MIN}(1 ; 1 ; 0,4 ; 0,4 ; 0,5)$

$=0,4$

$$
\text { Defuzzifikasi : }(95-\mathrm{z}) /(95-50) \quad=77 \quad=0,4
$$

- IF processor cukup AND harddisk rendah AND memory cukup AND vga cukup AND harga cukup THEN hasil memuaskan

$\alpha$-predikat (derajat keanggotaan terkecil/minimum):

$=\mu$ processor CUKUP ; $\mu$ harddisk RENDAH ; $\mu$ memory CUKUP; $\mu$ vga TINGGI; $\mu$ harga CUKUP

$=$ MIN ( $\mu$ processor CUKUP[75], $\mu$ harddisk RENDAH[70], $\mu$ memory CUKUP[85], $\mu$ vga CUKUP [85], $\mu$ harga

CUKUP[75])

$=\operatorname{MIN}(1 ; 1 ; 0,6 ; 0,4 ; 0,5)$

$=0,4$

$$
\begin{aligned}
\text { Defuzzifikasi : }(\mathrm{z}-50) /(95-50) & =0,4 \\
\mathrm{z} & =68
\end{aligned}
$$

-IF processor cukup AND harddisk rendah AND memory cukup AND vga cukup AND harga rendah THEN hasil memuaskan

$\alpha$-predikat (derajat keanggotaan terkecil/minimum):

$=\mu$ processor CUKUP; $\mu$ harddisk RENDAH $; \mu$ memory CUKUP $\mu$ vga TINGGI $; \mu$ harga CUKUP

$=$ MIN ( $\mu$ processor CUKUP[75], $\mu$ harddisk RENDAH[70], $\mu$ memory CUKUP[85], $\mu$ vga CUKUP [85], $\mu$ harga

CUKUP[75])

$=\operatorname{MIN}(1 ; 1 ; 0,6 ; 0,4 ; 0,5)$

$=0,4$

$$
\text { Defuzzifikasi : }(\mathrm{z}-50) /(95-50) \quad=68 \quad=0,4
$$

Kemudian dicari rata-rata terbobot dengan mengambil nilai-nilai dari implikasi dan defuzzifikasi.

$\mathrm{z}=\frac{0,4 * 68+0,4 * 68+0,5 * 72,5+0,5 * 72,50,4 * 77+0,4 * 77+0,4 * 68+0,4 * 68}{0,4+0,4+0,5+0,5+0,4+0,4+0,4+0,4}$

$\mathrm{z}=\frac{27,2+27,2+36,25+36,25+30,8+30,8+30,8+27,2+27,2}{3,4}$

$\mathrm{z}=\frac{242,9}{34}$

$\mathrm{z}=71,44$

Jadi Laptop yang bernama TOSHIBA untuk penilaian kriteria laptop bekas yang di rekomendasikan berdasarkan kriteria-kriteria yang sudah ditetapkan.

\subsection{Implementasi Program}

Pada tampilan menu utama, berisi beberapa menu untuk menuju ke halaman yang diinginkan. Menu tersebut adalah Menu File, Menu SPK dan Menu About Me. Tampilan menu utama dapat dilihat pada gambar 18 dibawah ini :

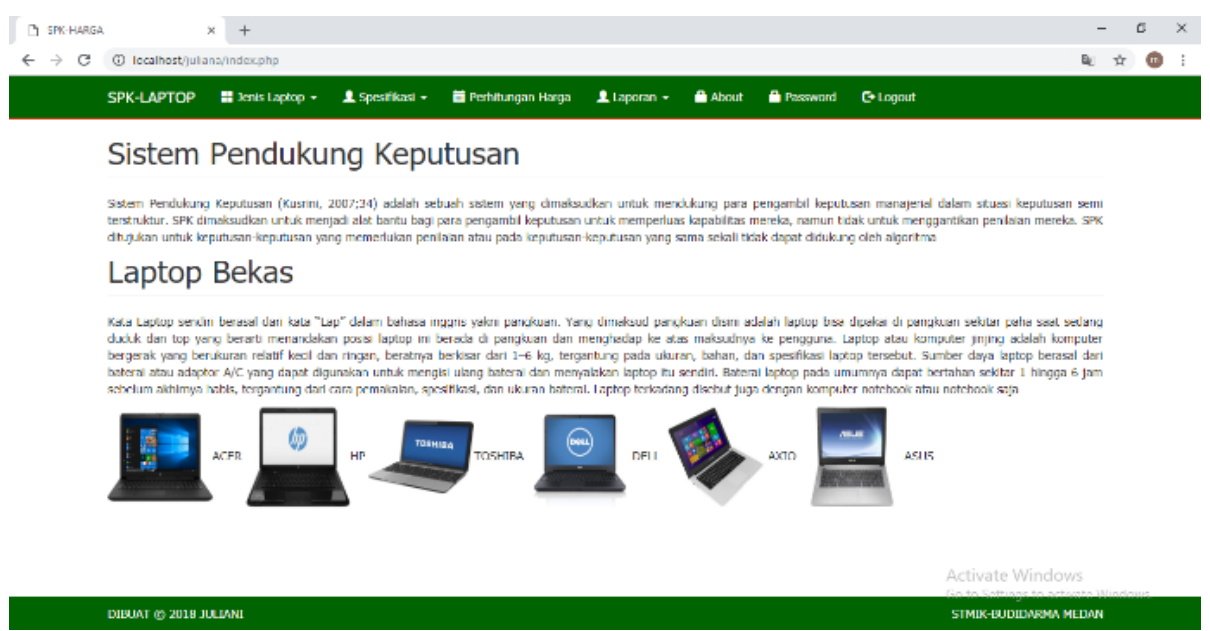

Gambar 18. Tampilan Form Menu Utama (Main Menu) 
Building of Informatics, Technology and Science (BITS)

Volume 2, No 2, December 2020 Page 115-126

ISSN 2684-8910 (media cetak)

ISSN 2685-3310 (media online)

Menu Jenis Laptop terdiri dari tambah jenis laptop. Sub menu data nama laptop berfungsi menampilkan halaman sub menu data dan jenis laptop yang kedua sedangkan tombol tambah berfungsi untuk menambah jenis laptop dapat dilihat pada gambar 19 di bawah ini :

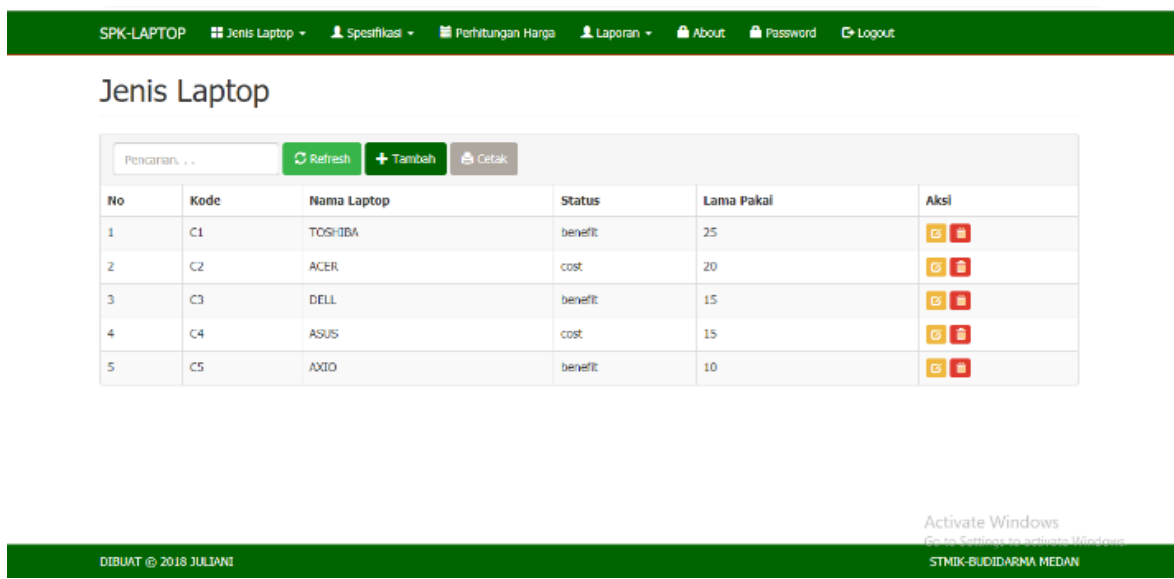

Gambar 19. Tampilan Form Menu Jenis Laptop

Pada saat sub menu spesifikaisi diklik maka akan menampilkan halaman spesifikasi laptop. Pada tampilan halaman data spesifikasi ini terdapat beberapa tombol yang berfungsi untuk mengubah atau menghapus dan menambah dpesifikasi laptop. Tampilan sub menu spesifikasi dapat lihat pada gambar 20 di bawah ini:

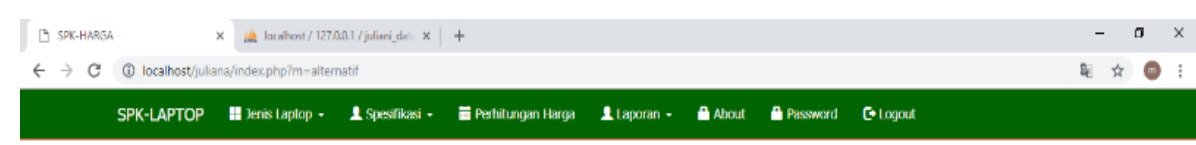

Spesifikasi Laptop

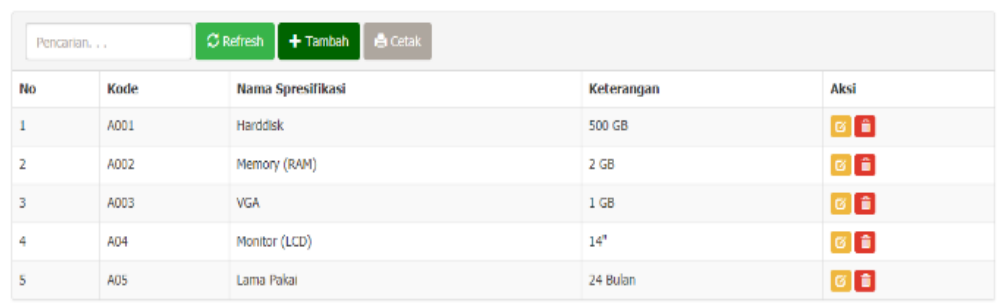

Gambar 20. Tampilan Form Sub Menu Data Spesifikai Laptop

Tampilan ini berisi perhitungan dengan fungsi keanggotaan untuk menentukan harga latop bekas berdasarkan perhitungan spesifikasi yang sudah ditentukan. Tampilan form menu perhitungan dapat dilihat pada gambar 21 dibawah ini.

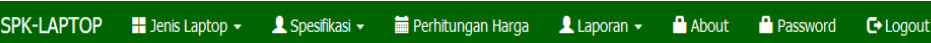

Perhitungan

\begin{tabular}{|l|l|l|l|l|l|l|}
\hline Hasil Analisa & ACER & DELL & ASUS & AXIO & HARGA \\
\hline \# & TOSHIBA & Mampu & Sangat Bagus & Mundur & 2 Juta-2,5 Juta \\
\hline Harddisk & Baik & Mampu & Mampu & Kurang Bagus & Bagus & 1 Juta-1,5 Juta \\
\hline Memory (RAM) & Sangat Baik & Cukup & Tidak mampu & Kurang Bagus & Bagus & 1,6 Juta-1,8 Juta \\
\hline VGA & Buruk & Cukup & Sangat Mampu & Sangat Bagus & Bagus & 1,5 Juta-1,9 Juta \\
\hline Monitor (LCD) & Baik & Cukup & Mampu & Masih Bagus & Bagus & 1 Juta-1,2 Juta \\
\hline Lama Pakai & Cukup & Sangat Mampu & & & \\
\hline
\end{tabular}

Gambar 21. Tampilan Form Menu Perhitungan Harga Laptop Bekas 
Building of Informatics, Technology and Science (BITS)

Volume 2, No 2, December 2020 Page 115-126

ISSN 2684-8910 (media cetak)

ISSN 2685-3310 (media online)

\section{KESIMPULAN}

Dari hasil eksperimen yang penulis lakukan terhadap penelitian ini penulis dapat menarik beberapa kesimpulan yang terkait dengan proses penelitian maupun dengan isi dari penelitian itu sendiri diantaranya hasil penilaian yang dilakukan oleh penulis maka menentukan harga laptop pada CV. Sumber Jaya Computer sudah bisa dilakukan dengan adanya kriteria-kriteria yang sudah ditentukan. Dengan diterapkannya metode fuzzy model tsukamoto dan dipreses dengan perhitungan fuzzy yang dibuat dengan model aplikasi dengan bahasa pemrograman PHP dengan berbasis desktop, maka bisa menentukan harga laptop bekas dengan spesifikasinya pada CV.Sumber Jaya Computer. Perancangan aplikasi penentuan harga laptop bekas yang berbasis web dan model desktop maka system pendukung keputusan penentuan harga laptop tersebut lebih akurat dalam mengambil keputusan.

\section{REFERENCES}

[1] N.Novita,"Metode Fuzzy Tsukamoto Untuk Menentukan Beasiswa", Jurnal \& Penelitian Teknik Informatika, Vol.1. 2016.

[2] Mulyan Ali," Penerapan Metode Fuzzy Tsukamoto Untuk Menentukan Jumlah Jam Overtime Pada Produksi Barang di PTAsahi Best Base Indonesia (ABBI) Bekasi”, Jurnal Informatika SIMANTIK, Vol.1. 2016.

[3] A.Kadir, Pengantar Sistem Informasi, Jakart, PT.Alex Media Komputindo (2003: 11)

[4] Tata Sutabri, Konsep Sistem Informasi, Andi Yogyakarta, 2001:24

[5] Husni Iskandar Pohan,Pengantar Perancangan Sistem, Andi Yogyakarta 2010:28

[6] Jogiyanto Hartono, Analisis Dan Disain, Andi Yogyakarta 2001:31

[7] Kusrini, Perancangan Sistim informasi, Alex Media Komputindo, 2002:23

[8] Sri Kusuma Dewi, Logika Metode Fuzzi, Perancangan Sistim informasi 2002:23

[9] Bin Ladjamuddin Al-bahra, “Analisis dan Desain Sistem Informasi”, Graha Ilmu, Yogyakarta, 2005

[10] F. Pratiwi, F. T. Waruwu, D. P. Utomo and R. Syahputra, "Penerapan Metode Aras Dalam Pemilihan Asisten Perkebunan Terbaik Pada PTPN V," Seminar Nasional Teknologi Komputer \& Sains (SAINTEKS), vol. 1, no. 1, pp. 651-662, 2019. 